\title{
Two tunnels for one peritoneal dialysis catheter: a case for caution
}

\author{
Volodymyr Chornyy, Abhilash Koratala, Amir Kazory
}

Division of Nephrology, Hypertension, and Renal Transplantation University of Florida College of Medicine, Gainesville, Florida, USA

\section{Correspondence to} Dr Amir Kazory, amir.kazory@medicine.ufl.edu

Accepted 7 October 2016

\section{CrossMark}

\footnotetext{
To cite: Chornyy $\mathrm{V}$,

Koratala A, Kazory A. BMJ

Case Rep Published online:

[please include Day Month

Year] doi:10.1136/bcr-2016-

217459
}

\section{DESCRIPTION}

Catheter tunnel infection (CTI) is a known cause of adverse outcomes in peritoneal dialysis (PD)-related peritonitis. Extension of exit site infection is the most common reported reason for CTI. We report a case of PD-related peritonitis due to a delayed surgical complication.

A man aged 54 years with a history of end-stage renal disease due to polycystic kidney disease, on continuous cycling PD for the past 5 years, presented with fever, abdominal pain and cloudy PD effluent. His abdomen was diffusely tender. Except for extruded external cuff, the PD catheter exit site was unremarkable. Serous drainage was noted 1 inch from the exit site where the surgical trocar had been inserted for laparoscopic PD catheter placement. The patient reported increasing drainage for 4 weeks prior to presentation. Laboratory studies were consistent with PD-related peritonitis with PD fluid white cell count of $470 / \mathrm{mm}^{3}$ and $64 \%$ neutrophils. Broad-spectrum antibiotics were initiated. The abundant drainage from the previously healed scar prompted further imaging.

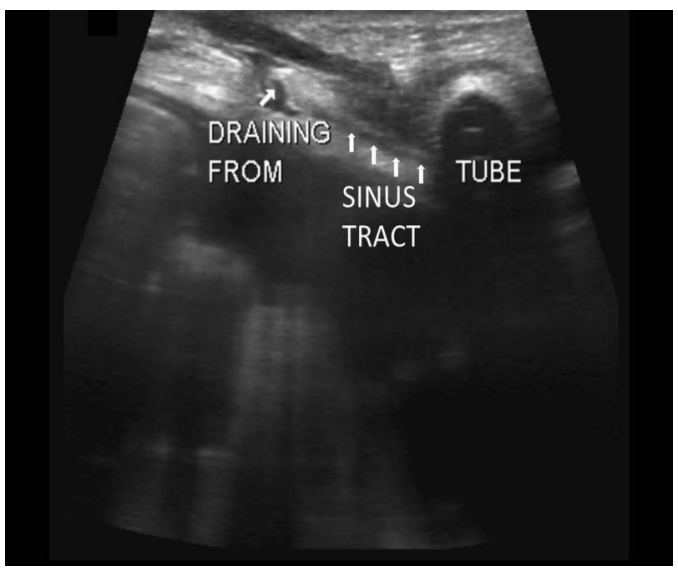

Figure 1 Abdominal ultrasound demonstrating the sinus tract (contiguous arrows) connecting the surgical trocar insertion site (drainage site) to the inner segment of the peritoneal dialysis catheter tunnel (labelled as 'tube').
Interestingly, the abdominal ultrasound study revealed a 1.5 inch sinus tract connecting the surgical trocar insertion site to the inner segment of the catheter tunnel (figure 1). Although the patient deteriorated initially, removal of the PD catheter resulted in resolution of the infection and progressive improvement in his clinical status.

\section{Learning points}

- This case demonstrates the importance of appropriate imaging study in evaluation of unexplained peritoneal dialysis (PD)-related peritonitis even without overt symptoms of exit site infection.

- Sinus formation should be considered when a previously healed scar develops abundant drainage.

- While laparoscopic PD catheter insertion is superior to open or peritoneoscopic surgery in terms of complications, ${ }^{12}$ if technically feasible, it is prudent to insert the surgical trocar as far as possible from the exit site and the catheter tunnel to avoid late-appearing surgical complications.

Contributors VC and AKo have procured the images and prepared preliminary manuscript. AKa has revised the manuscript and approved for final submission.

Competing interests None declared.

Patient consent Obtained.

Provenance and peer review Not commissioned; externally peer reviewed.

\section{REFERENCES}

1 Chen $Y$, Shao $Y, X u$ J. The survival and complication rates of laparoscopic versus open catheter placement in peritoneal dialysis patients: a meta-analysis. Surg Laparosc Endosc Percutan Tech 2015;25:440-3.

2 Sun TY, Voss D, Beechey D, et al. Comparison of peritoneal dialysis catheter insertion techniques: peritoneoscopic, radiological and laparoscopic: a single-centre study. Nephrology (Carlton) 2016;21:416-22. 
Copyright 2016 BMJ Publishing Group. All rights reserved. For permission to reuse any of this content visit http://group.bmj.com/group/rights-licensing/permissions.

BMJ Case Report Fellows may re-use this article for personal use and teaching without any further permission.

Become a Fellow of BMJ Case Reports today and you can:

- Submit as many cases as you like

- Enjoy fast sympathetic peer review and rapid publication of accepted articles

- Access all the published articles

- Re-use any of the published material for personal use and teaching without further permission

For information on Institutional Fellowships contact consortiasales@bmjgroup.com

Visit casereports.bmj.com for more articles like this and to become a Fellow 